\title{
PARTISIPASI WARGA MASYARAKAT DALAM PENILAIAN KINERJA KECAMATAN DI KOTA BANDUNG
}

\author{
Novie Indrawati Sagita \\ Departemen Ilmu Pemerintahan FISIP \\ Universitas Padjadjaran \\ e-mail:novindsa@gmail.com
}

\begin{abstract}
ABSTRAK
Sistem Informasi Penilaian (SIP) Bandung Juara merupakan aplikasi berbasis teknologi informasi yang bertujuan memudahkan dalam evaluasi pencapaian kontrak kinerja kecamatan. SIP Bandung Juara ini pula sebagai wadah partisipasi publik dalam menilai kinerja layanan publik yang dilakukan kecamatan di Kota Bandung. Metode yang digunakan pada penelitian ini adalah metode kualitatif yang bersifat deskriptif dengan maksud memberikan gambaran mengenai pelaksanaan partisipasi masyarakat Kota Bandung dalam memantau dan mengevaluasi kinerja kecamatan. Partisipasi publik yang dibahas pada penelitian ini sebagaimana menurut Cohen dan Uphoff (1977) termasuk dalam jenis participation in evaluation yakni bentuk partisipasi masyarakat melalui keikutsertaan mengawasi kegiatan dan menilai kinerja pemerintah. Penelitian ini menghasilkan kesimpulan bahwa menurut penilaian masyarakat, pencapaian kinerja kecamatan belum mencapai tujuan yang diharapkan, kualitas layanan yang kurang baik, dan rata-rata waktu pelayanan yang dapat diselesaikan oleh kecamatan sebagian besar masih dalam rentang diatas 1 minggu hingga hitungan bulan. Namun sayangnya, partisipasi masyarakat Kota Bandung dalam mengevaluasi kinerja pemerintah kecamatan melalui aplikasi Sistem Informasi Penilaian (SIP) Bandung Juara tersebut masih terbilang rendah. Sejak aplikasi SIP diluncurkan pertama kali pada tahun 2014, hanya beberapa orang saja yang bersedia mengisi penilaian di SIP Bandung Juara. Minimnya partisipasi warga masyarakat Kota Bandung menunjukkan bahwa aplikasi SIP Bandung Juara belum sepenuhnya dimanfaatkan. Oleh karena itu, Pemerintah Kota Bandung perlu meningkatkan intensitas sosialisasi aplikasi Sistem Informasi Penilaian (SIP) Bandung Juara. Sehingga, hasil evaluasi masyarakat dapat menunjukkan kualitas penilaian kinerja kecamatan yang sesungguhnya.
\end{abstract}

Kata Kunci: Sistem Informasi Penilaian, partisipasi masyarakat, kinerja pemerintah

\begin{abstract}
Assessment Information System (SIP Bandung Juara) is an application based on information technology that aims to facilitate Bandung City Government to evaluate the achievement of the performance contract of their districts (kecamatan). SIP Bandung Juara also as a forum for public participation in assessing the performance of public services that have been performed by the districts government (kecamatan) in the city of Bandung. The method used in this study is a qualitative descriptive with the purpose of providing an overview of the implementation of Bandung public participation in monitoring and evaluating the performance of districts government. Public participation are discussed in this study as well as according to Cohen and Uphoff (1977) included in this type of participation is in the evaluation form of public participation by monitoring the activities and to assess the government's performance.This research resulted in the conclusion that the judgment of the public, the performance achievement of districts government have not yet reached the expected goals, the quality of service is not good, and the average service time that can be completed by most of the districts government
\end{abstract}


are still within the range of above 1 week to a few months. Unfortunately, the public participation in Bandung in evaluating the performance of the district governments through the application of Assessment Information Systems (SIP) Bandung Juara is still fairly low. Since SIP application was first launched in 2014, only a few people who are willing to fill votes in the SIP Bandung Juara. The lack of public participation in Bandung shows that application of SIP Bandung Juara has not been fully utilized. Therefore, the Government of Bandung City need to increase the intensity of socialization application Assessment Information System (SIP) Bandung Juara. Thus, the results of the public evaluation can demonstrate the actual performance quality of districts government.

Keywords: Assessment Information System, public participation, performance of government

\section{PENDAHULUAN}

Sistem tata kelola pemerintahan di Indonesia berlandaskan pada prinsip-prinsip good governance, yang mana salah satunya prinsip yang harus dijalankan adalah melibatkan partisipasi masyarakat dalam setiap penyelenggaraan pemerintah dan pembangunan. Keterlibatan masyarakat tersebut merupakan wujud dari pemerintahan demokratis dimana masyarakat diberi kesempatan yang luas untuk ikut merencanakan pembangunan sesuai dengan kebutuhan yang diinginkan masyarakat. Tidak hanya pada aspek perencanaan, keterlibatan masyarakat juga menghendaki dukungan dalam pelaksanaan pembangunan dan pelayanan umum, ikut menikmati hasil-hasil pembangunan dan pelayanan, sekaligus memantau dan mengevaluasi kinerja pemerintahan baik pemerintahan di tingkat pusat maupun di daerah. Selain partisipasi, prinsip-prinsip good governance lainnya seperti transparansi dan akuntabilitas harus diwujudkan dalam

penyelenggaraan

pemerintahan.

Di Kota Bandung, keterlibatan masyarakat untuk menilai secara terbuka terhadap kinerja aparatur pemerintahan sudah dimulai sejak kepemimpinan Walikota Ridwan Kamil dan Wakil Walikota Oded M.Danial. Mulanya, penilaian tersebut disampaikan melalui sosial media yakni Facebook dan Twitter. Namun demikian, penilaian kinerja aparatur dan kinerja instansi di seluruh Kota Bandung yang disampaikan masyarakat melalui media sosial tersebut dinilai tidak terukur. Oleh karena itu, dalam rangka mendorong kinerja pemerintahan (khususnya di kecamatan), maka Sekretariat Daerah Pemerintah Kota Bandung melalui Bagian Pemerintahan Umum berinisiatif untuk membuat inovasi sistem penilaian kinerja kecamatan yang berbasis teknologi informasi dan internet. Penggunaan teknologi informasi dan basis internet tersebut sesuai dengan misi Walikota Ridwan Kamil dan Wakil Walikota Oded M. Danial untuk mewujudkan Bandung 
Kota Pintar atau "smart city", yakni pemanfaatan teknologi informasi dalam semua pengelolaan, koordinasi dan komunikasi antar instansi di lingkungan Pemerintah Kota Bandung, maupun interaksi pemerintah dengan masyarakat agar dapat berlangsung secara efektif dan efisien.

Inovasi sistem penilaian yang dimaksud adalah Sistem Informasi Penilaian (SIP) Bandung Juara. Aplikasi ini pertama kali diluncurkan Pemerintah Kota Bandung pada tahun 2014. SIP Bandung Juara merupakan media pelaporan kecamatan dan kelurahan terkait kontrak kinerja, diantaranya melaporkan kegiatan rutin bulanan, laporan tahunan terkait ketersediaan dan pencapaian kinerja, dan laporan insidental yakni laporan yang diminta pimpinan. SIP Bandung Juara juga sebagai media pengumpulan data bagi pimpinan dalam pengambilan keputusan, dan didalamnya terdapat album kegiatan untuk mewadahi kegiatan-kegiatan tambahan yang dilakukan kecamatan dan kelurahan yang tidak ada dalam slot perjanjian kinerja. Pada SIP Bandung Juara juga terdapat menu file-file pendukung yang diperlukan aparatur pemerintah kecamatan dan kelurahan berupa peraturan-peraturan yang berlaku di kewilayahan misalnya peraturan perundangundangan terkait pemerintahan dan otonomi daerah, peraturan walikota tentang pelimpahan kewenangan, peraturan walikota tentang PIPPK (Program Inovasi Pembangunan dan
Pemberdayaan Kewilayahan), juklak-juknis PIPPK, surat-surat edaran, bahan-bahan sosialisasi tentang program pemerintah, materimateri pelatihan, materi bimbingan teknis, format-format yang dibutuhkan di kewilayahan, dan bahan materi lainnya yang mendukung kegiatan kewilayahan.

Aplikasi SIP Bandung Juara ini sesungguhnya bertujuan untuk memudahkan pemerintah di tingkat kewilayahan dalam melaksanakan tugas-tugas yang dilimpahkan kepadanya. Selain itu, aplikasi SIP Bandung Juara juga sebagai media komunikasi dan wadah bagi masyarakat untuk memberikan penilaian kinerja kecamatan dan kelurahan. Penilaian dari masyarakat terkait kinerja kecamatan sebagai bentuk transparansi dan akuntabilitas yang dianggap penting agar dapat meningkatkan kualitas penyelenggaraan pemerintahan dan pelayanan publik di kewilayahan yang jauh lebih baik.

\section{TINJAUAN PUSTAKA}

Terdapat beberapa definisi terkait partisipasi (masyarakat), diantaranya menurut Davis (1962) sebagaimana dikutip oleh Rathnakar (2012: 136) mengatakan participation is define as mental and emotional envolvement of a person in a group situation which encourages him to contribute to group goals and share responsibilities in them. Berdasarkan pernyataan Davis tentang definisi diatas, maka partisipasi dapat diartikan sebagai 
keterlibatan mental dan emosional seorang individu dalam situasi kelompok tertentu yang mendorongnya untuk berkontribusi untuk mencapai tujuan kelompok dan berbagi tanggung jawab didalam pencapaian tujuan tersebut. Lebih lanjut Davis mengatakan bahwa kontribusi masyarakat dalam pencapaian tujuan (manajemen) pembangunan tersebut dilakukan dalam tiap-tiap tahapan mulai dari perencanaan perumusan agenda kerja pembangunan, pelaksanaan pembangunan, hingga evaluasi kegiatan pembangunan.

Masih terkait dengan definisi partisipasi, Siagian berpendapat bahwa partisipasi itu ada yang bersifat aktif dan ada juga partisipasi yang bersifat pasif. Partisipasi yang bersifat pasif berarti bahwa dalam sikap, perilaku dan tindakannya tidak melakukan hal-hal yang mengakibatkan terhambatnya suatu kegiatan pembangunan. Selanjutnya, masih menurut Siagian, partisipasi aktif berwujud sebagai berikut:

$\begin{array}{lr}\text { “ Turut } & \text { memikirkan } \\ \text { nasib sendiri } & \text { dengan } \\ \text { memanfaatkan } & \text { lembaga- } \\ \text { lembaga sosial dan politik } \\ \text { yang ada di masyarakat } \\ \text { sebagai saluran aspirasinya. } \\ \text { Menunjukkan adanya } \\ \text { kesadaran bermasyarakat } \\ \text { dan bernegara yang tinggi } \\ \text { dengan tidak menyerahkan } \\ \text { nasib kepada orang lain, } \\ \text { seperti kepada pimpinan, } \\ \text { kelompok masyarakat, baik }\end{array}$

yang sifatnya formal maupun informal; memenuhi kewajiban sebagai warga negara yang bertanggung jawab seperti membayar pajak secara jujur serta berkewajiban lainnya; ketaatan kepada berbagai peraturan perundangundangan yang berlaku dan kerelaan melakukan pengorbanan yang dituntut oleh pembangunan demi kepentingan bersama yang luas dan penting".

Berdasarkan definisi-definisi yang dinyatakan diatas maka paradigma penyelenggaraan pemerintahan saat ini (good governance) salah satunya mencantumkan prinsip partisipasi yang memberikan peluang bagi masyarakat untuk ikut berkontribusi merencanakan, mensukseskan, dan mengevaluasi hasil-hasil pembangunan, penyelenggaraan pemerintahan, dan evaluasi kinerja pelayanan publik yang dilakukan oleh pemerintah (daerah). Dengan melakukan tindakan-tindakan tersebut, berarti masyarakat sudah turut aktif memikirkan pemenuhan kebutuhan hidup dan penghidupannya demi masa depan yang lebih baik.

Menurut Conyers (1994: 154155), partisipasi masyarakat memiliki arti sangat penting dalam pelaksanaan pembangun. Terdapat tiga alasan mengapa partisipasi masyarakat diperlukan, yakni : 1 . 
Masyarakat merupakan sumber informasi yang memberikan gambaran tentang kondisi dan kebutuhan daerah setempat; 2 . Masyarakat akan lebih percaya kepada program kegiatan pembangunan bilamana mereka dilibatkan dalam perencanaan, serta memiliki tanggung jawab dan kepedulian untuk menyukseskan pelaksanaannya karena adanya rasa memiliki terhadap program dan kegiatan tersebut; 3. Keterlibatan masyarakat sebagai bentuk terlaksananya hak demokrasi untuk turut serta menentukan dan memantau terlaksananya pembangunan. Partisipasi masyarakat dapat diwujudkan atas dasar inisiatif masyarakat sendiri, artinya masyarakat berpartisipasi atas kesadarannya sendiri untuk mendukung program pemerintah atau berinisiatif mewujudkan kondisi yang ia inginkan. Selain itu, partisipasi masyarakat juga dapat terwujud apabila diminta, artinya partisipasi ada apabila pemerintah meminta atau memaksa masyarakat untuk melakukannya. Partisipasi bentuk lain adalah keterlibatan masyarakat atas adanya timbal balik finansial atau karena adanya insentif, yakni partisipasi yang dilakukan masyarakat bukan atas kesadaran sendiri melainkan adanya imingiming bayaran atau insentif tertentu apabila dilakukan.

Sependapat dengan Conyers diatas, Cohen dan Uphoff (1977: 92) berpendapat bahwa partisipasi merupakan bentuk kepedulian masyarakat untuk mengambil bagian atau peran dalam pembangunan. Partisipasi masyarakat berwujud dalam berbagai bentuk diantaranya menyampaikan pernyataan dan tanggapan tentang pelaksanaan atau hasil pembangunaan yang dirasakan, menyumbangkan tenaga, waktu, memberikan masukan berupa ide, gagasan, pemikiran tentang model atau rencana pembangunan yang harus dilakukan, atau bahkan turut serta menyumbangklan materi atau ikut menanggung biaya agar pembangunan terlaksana sesuai tujuan dan harapan. Masih menurut Cohen dan Uphoff (1977), partisipasi masyarakat dapat dibedakan atas 4 jenis yaitu a) participation in decision making; b) participation in implementation; c) participation in benefits; d) participation in evaluation.

Participation in decision making merupakan keterlibatan masyarakat dalam memberikan masukan pemikiran terkait perencanaan program kerja dan keputusan-keputusan mengenai prioritas pembangunan. Selanjutnya, Participation in implementation merupakan keterlibatan masyarakat untuk ikut serta dalam mendukung terlaksananya pembangunan baik kontribusi dalam memberikan tenaga, bahan baku maupun finansial dengan memberikan sumbangan pembiayaan bagi terselengaranya pembangunan. Bentuk partisipasi berikutnya adalah Participation in benefits yang merupakan bentuk keterlibatan masyarakat untuk turut 
menikmati dan memanfaatkan hasilhasil pembangunan yang sudah terlaksana. Bukan hanya menikmati, tetapi masyarakat juga diharapkan dapat berpartisipasi dalam menjaga, merawat, dan memelihara hasil-hasil pembangunan yang telah dilakukan. Pemanfaatan hasil pembangunan tersebut diharapkan dapat mengungkit daya kreatifitas masyarakat, kegiatan ekonomi dan mobilitas sosial, peningkatan kesejahteraan masyarakat, yang pada akhirnya dapat mencapai pembangunan yang lebih baik lagi. Bentuk partisipasi yang terakhir adalah participation in evaluation yakni bentuk partisipasi masyarakat melalui keikutsertaan mengawasi kegiatan dan menilai kinerja pembangunan serta hasil-hasilnya. Bentuk partisipasi terakhir inilah (participation in evaluation) yang menjadi bahasan dalam penelitian ini.

Kinerja atau dalam terminologi dalam bahasa Inggris sering disebut dengan istilah performance didefinisikan sebagai degree of accomplishment atau tingkat pencapaian hasil dari pekerjaan atau pencapaian tujuan (Rue and Byar dalam Keban, 2004). Selain tingkat pencapaian hasil atau tujuan, kinerja juga dapat diartikan sebagai prestasi atas penyelenggaraan suatu pekerjaan (Atmosudirdjo, 1997). Prestasi atas pekerjaan diindikasikan dari tingkat pelaksanaan tugas dan kesesuaiannya dengan visi dan misi yang telah ditetapkan. Melalui pencapaian kinerja dapat diukur keberhasilan suatu organisasi (pemerintah) menjalankan program pembangunan serta pelayanan publik dalam penyelenggaraan pemerintahan. Menurut Sendjaja, dkk (2008: 71), kinerja organisasi dapat diukur melalui sejauh mana tingkat kesesuaian antara aktualisasi program dan kegiatan dengan tujuantujuan yang telah ditetapkan. Kesesuaian tersebut dapat dilihat dari pemenuhan 3 aspek yaitu efektif, efisien, dan ekonomis. Bukan itu saja, bahkan pencapaian kinerja juga dapat diukur dengan cara mengevaluasi sejauh mana program dan kegiatan yang dijalankan organisasi (pemerintah) tersebut dapat memberikan manfaat bagi masyarakat.

Sistem

Pemerintahan Indonesia menganut prinsip otonomi daerah dan asas desentralisasi. Melalui pelaksanaan otonomi daerah dan desentralisasi tersebut, penyelenggaraan urusan pemerintahan, pelaksanaan pembangunan dan pelayanan publik dititikberatkan pada daerah khususnya kabupaten/kota. Dalam rangka menyelenggaraan urusan pemerintahan tersebut, pemerintah membentuk unit-unit kerja yang dibentuk untuk membantu penyelenggaraan urusan pemerintahan di daerah. Berdasarkan Pasal 221 Undang-Undang Nomor 23 Tahun 2014, disebutkan bahwa daerah kabupaten/kota membentuk kecamatan dalam rangka meningkatkan koordinasi, 
penyelenggaraan pemerintahan, pelayanan publik, dan pemberdayaan masyarakat desa/kelurahan. Berdasarkan UU pemerintahan daerah tersebut di atas maka kecamatan dan kelurahan menjadi ujung tombak penyelenggaraan pemerintahan daerah.

\section{METODE PENELITIAN}

Penelitian ini menggunakan metode deskriptif kualitatif. Berdasarkan definisinya, yang dimaksud dengan penelitian deskriptif kualitatif menurut Bogdan dan Taylor (dalam Moleong, 2011: 4) adalah penelitian yang menggambarkan dengan kata-kata tertulis mengenai suatu fenomena (tindakan dan perilaku) yang diamati/diteliti. Penelitian ini dilakukan untuk menggambarkan sekaligus menganalisis mengenai partisipasi yang dilakukan masyarakat dalam memberikan penilaian terhadap kinerja pemerintah kecamatan dalam memberikan pelayanan serta pencapaian misi Walikota Bandung sebagai Kota Bandung Juara.

Analisis penelitian ini menggunakan data primer dan data sekunder. Perolehan data primer yang dilakukan selama proses penelitian menggunakan teknik wawancara terstruktur dengan aparatur pemerintah di Bagian Pemerintahan Umum Sekretariat Daerah Kota Bandung selaku pembina kecamatan dan kelurahan di Kota Bandung dan wawancara dengan beberapa camat di Kota
Bandung. Adapun camat yang diwawancarai adalah kecamatan yang mendapat nilai dengan kategori tertinggi, sedang dan terendah dari masyarakat. Disamping data primer, analisis penenelitian ini juga menggunakan data sekunder, yakni data mengenai hasil penilaian masyarakat terhadap kinerja kecamatan melalui aplikasi SIP (Sistem Informasi Penilaian) Bandung Juara.

\section{HASIL PENELITIAN DAN PEMBAHASAN}

Pemerintah Kota Bandung di bawah kepemimpinan Ridwan Kamil (selaku walikota) dan Oded M. Danial (selaku wakil walikota) menerapkan konsep pengelolaan pemerintahan yang ditopang oleh 3 (tiga) pilar yaitu desentralisasi, inovasi, dan kolaborasi. Pilar desentralisasi diterapkan melalui Peraturan Walikota Nomor 185 Tahun 2015 tentang Pelimpahan Sebagian Urusan Walikota kepada Camat dan Lurah. Berdasarkan peraturan walikota tersebut, pelimpahan urusan menjadi hak dan kewajiban camat untuk menentukan atau mengambil kebijakan dalam rangka penyelenggaraan pemerintahan di lingkungan kecamatan. Pelimpahan urusan ini merupakan arah kebijakan, program dan kegiatan Pemerintah Kota Bandung untuk meningkatkan efektifitas dan efisiensi pelayanan kepada masyarakat dan penguatan peran kewilayahan. Pelaksanaan pelimpahan urusan ini dituangkan 
dalam kontrak kinerja camat kepada walikota, sebagai bentuk komitmen camat untuk melaksanakan pelimapahan urusan tersebut. Adapun pilar inovasi dilakukan oleh Pemerintah Kota Bandung dengan cara memanfaatkan teknologi informasi untuk mendukung program kerjanya. Penggunaan teknologi informasi ini merupakan semangat perubahan kepemimpinan dan penyelenggaraan pemerintahan yang hendak mewujudkan Kota Bandung sebagai Kota Pintar (smart city). Banyak proses administrasi dan pelayanan publik oleh Pemerintah Kota Bandung yang telah dilakukan secara online. Penggunaan teknologi informasi diharapkan mampu menjadikan pemerintah Kota Bandung yang bersih dan terbuka. Adapun pilar kolaborasi, diantaranya melakukan kerjasama dengan masyarakat untuk menilai kinerja kecamatan dalam rangka mewujudkan transparansi dan akuntabilitas pemerintahan.

Salah satu bentuk inovasikolaborasi serta pemanfaatan teknologi informasi dilakukan Pemerintah Kota Bandung diantaranya dengan membangun Sistem Informasi Penilaian (SIP) bagi kinerja kecamatan dan kelurahan dimana partisipasi publik menjadi salah satu indikator penilaiannya. Sistem itu merupakan aplikasi berbasis teknologi informasi yang dikenal dengan Sistem Informasi Penilaian (SIP) Bandung Juara. SIP Bandung Juara ini merupakan sebuah sistem informasi penilaian yang mewadahi partisipasi publik untuk menilai kinerja layanan yang dilakukan kecamatan di Kota Bandung.

Sebelum aplikasi ini dibangun, sesungguhnya partisipasi masyarakat dalam penilaian kinerja pemerintah kecamatan/kelurahan setempat dilakukan melalui sarana media sosial yaitu Twitter dan Facebook. Namun, melalui aplikasi SIP Bandung Juara ini, warga Kota Bandung yang telah memperoleh pelayanan di kecamatan dapat langsung mengapresiasi, mengevaluasi serta memberikan penilaian secara online terhadap kinerja yang telah dilakukan kecamatan. Selain memberikan penilaian langsung terhadap kinerja jajaran aparat di kecamatan, masyarakat juga dapat langsung melaporkan setiap kondisi atau permasalahan yang terjadi di lingkungan mereka ${ }^{1}$.

Pada aplikasi SIP Bandung Juara terdapat 2 (dua) kriteria penilaian yaitu pertama, kriteria penilaian warga terhadap kinerja kecamatan meliputi ketertiban, keindahan, kebersihan, indeks kebahagiaan, dan program ngabandungan, serta penilaian kedua, mengenai kualitas pelayanan yang diberikan dan rata-rata waktu pelayanan. Hasil penilaian warga masyarakat tersebut menjadi bahan

\footnotetext{
${ }^{1}$ Pernyataan MN dalam wawancara tanggal 15 Agustus 2016. Website SIP Bandung Juara ini bukan hanya aplikasi untuk menilai kinerja kecamatan juga untuk menilai kinerja kelurahan.
} 
penilaian walikota untuk memberikan rapor kecamatan.

Penilaian warga masyarakat terhadap kriteria pertama, yakni kriteria penilaian warga terhadap kinerja kecamatan meliputi ketertiban, keindahan, kebersihan, indeks kebahagiaan, dan program ngabandungan, ditentukan berdasarkan skala penilaian 1-5, untuk nilai 5 berarti termasuk kategori penilaian dari masyarakat sangat baik, nilai indeks 4 untuk kategori penilaian baik, nilai indeks 3 untuk kategori penilaian cukup baik, nilai indeks 2 untuk kategori penilaian kurang baik, dan nilai indeks 1 untuk kategori penilaian sangat kurang atau buruk. Hasil penilaian tersebut langsung diisikan oleh masyarakat dengan terlebih dahulu memasuki website SIP Bandung Juara. Masyarakat yang memberikan penilaian adalah masyarakat yang tinggal di wilayah setempat dan/atau masyarakat yang memperoleh layanan di kecamatan. Penilaian masyarakat tersebut dapat langsung diberikan melalui komputer yang disediakan di kecamatan, melakukan penilaian di rumah sendiri atau melalui telepon genggam atau ponsel masing-masing.

Hasil penilaian masyarakat terhadap kinerja di 30 kecamatan di Kota Bandung berdasarkan kategori penilaian ketertiban, keindahan, kebersihan, indeks kebahagiaan, dan program ngabandungan mendapatkan nilai paling tinggi dengan indeks 3,60 (kategori cukup baik) yakni untuk kecamatan Bandung Kidul. Sedangkan kecamatan yang mendapatkan penilaian paling rendah dengan indeks penilaian 1,79 (kategori sangat kurang baik atau buruk) adalah Kecamatan Bojongloa Kaler. Sebagian besar lagi, masyarakat menilai kinerja kecamatan dalam mewujudkan ketertiban, keindahan, kebersihan, indeks kebahagiaan, dan program ngabandungan dengan penilaian rata-rata pada kategori kurang baik (indeks 2). Penilaian masyarakat terhadap kinerja kecamatan tersebut secara lengkap dapat dilihat pada tabel 1 berikut.

Tabel 1. Rata-Rata Penilaian Warga Terhadap Kinerja Kecamatan dalam Mewujudkan Ketertiban, Keindahan, Kebersihan, Indeks Kebahagiaan, dan Program Ngabandungan Di Kota Bandung

\begin{tabular}{|c|l|c|c|l|c|}
\hline No & \multicolumn{1}{|c|}{ Kecamatan } & $\begin{array}{c}\text { Indeks } \\
\text { Penilaian }\end{array}$ & No & Kecamatan & $\begin{array}{c}\text { Indeks } \\
\text { Penilaian }\end{array}$ \\
\hline 1 & Bandung Kidul & 3,60 & 16 & Regol & 2,44 \\
\hline 2 & Andir & 3,36 & 17 & Bandung Wetan & 2,43 \\
\hline 3 & Ujung Berung & 3,30 & 18 & Lengkong & 2,40 \\
\hline 4 & Sumur Bandung & 3,00 & 19 & Bojongloa Kidul & 2,35 \\
\hline 5 & Panyileukan & 2,96 & 20 & Buah Batu & 2,35 \\
\hline 6 & Cicendo & 2,65 & 21 & Sukasari & 2,29 \\
\hline 7 & Mandalajati & 2,65 & 22 & Astana Anyar & 2,29 \\
\hline
\end{tabular}




\begin{tabular}{|c|l|c|c|l|c|}
\hline 8 & Cibeunying Kidul & 2,63 & 23 & Rancasari & 2,28 \\
\hline 9 & Gede Bage & 2,61 & 24 & Babakan Ciparay & 2,04 \\
\hline 10 & Arcamanik & 2,58 & 25 & Cidadap & 2,00 \\
\hline 11 & Batununggal & 2,57 & 26 & Cibeunying Kaler & 1,92 \\
\hline 12 & Antapani & 2,54 & 27 & Bandung Kulon & 1,88 \\
\hline 13 & Sukajadi & 2,53 & 28 & Kiaracondong & 1,87 \\
\hline 14 & Coblong & 2,53 & 29 & Cinambo & 1,86 \\
\hline 15 & Cibiru & 2,46 & 30 & Bojongloa Kaler & 1,79 \\
\hline
\end{tabular}

Sumber : Bagian Pemerintahan Umum Sekretariat Daerah Kota Bandung, 2016

Berdasarkan penilaian masyarakat terhadap kinerja kecamatan tersebut (meliputi ketertiban, keindahan, kebersihan, indeks kebahagiaan, dan program ngabandungan) 4 kecamatan memperoleh penilaian tertinggi yakni Kecamatan Bandung Kidul, Andir, Ujung Berung, dan Kecamatan Sumur Bandung dengan indeks 3 (cukup baik). 5 kecamatan mendapatkan penilaian kinerja sangat kurang atau buruk yaitu Kecamatan Cibeunying Kaler, Bandung Kulon, Kiaracondong, Cinambo, dan Bojongloa Kaler. Sedangkan sebagian besar kecamatan di Kota Bandung, mendapatkan penilaian dari masyarakat dengan indeks 2 (kurang baik). Penilaian ini menunjukkan bahwa kinerja kecamatan di Kota Bandung masih belum dapat memberikan kepuasan kepada masyarakat terkait ketertiban, keindahan, kebersihan, indeks kebahagiaan, dan program ngabandungan. Padalah program ini sesungguhnya sudah menjadi janji politik Walikota Ridwan Kamil dan Wakil Walikota Oded M.Danial semasa kampanye. Pelaksanaan program ketertiban, keindahan, kebersihan (K3) tersebut diantaranya diwujudkan melalui Program PIPPK dengan memberikan bantuan kepada kecamatan, kelurahan dan masyarakat. Salah satu kegiatan dari Program PIPPK tersebut adalah memprioritaskan pada pembelian alat-alat kebersihan, pengelolaan sampah di lingkungan pemukiman dan penyediaan sarana prasarananya, serta pembuatan taman-taman RW. Hanya saja masalah K3 memang tampaknya belum terlaksana efektif. Hal ini dapat dilihat dari kondisi meskipun pemerintah Kota Bandung telah menyediakan sarana prasarana pengelolaan sampah, namun masalah penanganan sampah belum cukup baik. Begitupula dengan pembangunan taman-taman RW yang hingga kini belum terealisasi dengan baik. Penanganan masalah K3 sebenarnya tidak hanya menjadi tanggung jawab kecamatan dan kelurahan melainkan juga menjadi tanggung jawab masyarakat untuk mendukung pelaksanaannya. Misalnya masih ada masyarakat yang belum tertib dan dengan penuh kesadaran untuk membuang sampah pada tempatnya serta menjaga 
kebersihan dan keindahan lingkungan di wilayah tempat tinggalnya. Dalam hal pengelolaan K3, masyarakat masih menyerahkan urusannya kepada pemerintah, tanpa adanya kesadaran bahwa masyarakat juga turut bertanggungjawab ataskeberhasilan pencapaian K3 tersebut. Penilaian dari masyarakat ini tentunya menjadi umpan balik bagi kecamatan sekaligus Pemerintah Kota Bandung, khususnya mengenai K3, Pemerintah Kota dan Kecamatan harus lebih intensif dalam sosialisasi Perda K3 kepada masyarakat, disamping pentingnya penegakan hukum agar masyarakat tertib untuk turut menjaga ketertiban, keindahan dan kebersihan di lingkungannya.

Kemudian untuk penilaian indeks kebahagiaan yang belum mendapat apresiasi yang baik dari masyarakat pada saat penilaian kinerja kecamatan agaknya cukup bertentangan dengan hasil survei tentang Indeks Kebahagiaan Masyarakat Kota Bandung yang pernah dilakukan pada tahun 2015 . Hasil penilaian masyarakat di kecamatan sebagian besar memberikan penilaian kurang baik, namun hasil survei menunjukkan bahwa indeks kebahagiaan masyarakat Kota Bandung cukup tinggi sebesar 70,60 dari skala 0-100. Penilaian indeks kebahagiaan ini mengalami peningkatan pada tahun sebelumnya yang hanya mencapai indeks 60,32 di tahun 2014. Bagaimanapun penilaian dari masyarakat di tingkat kecamatan merupakan penilaian yang lebih riil terkait indeks kebahagiaan. Artinya variabel tingkat pendapatan, kesehatan, pendidikan, harmonisasi sosial dan keamanan lingkungan yang menjadi indikator indeks kebahagiaan tersebut belum cukup menggambarkan kebahagiaan masyarakat yang sesungguhnya. Masyarakat juga memimpikan kehidupan yang nyaman, aman, tertib, bersih, indah dan harmonis di lingkungan tempat tinggalnya. Oleh karena itu, tugas pemerintah Kota Bandung untuk mendorong kecamatan dan kelurahan mewujudkan tempat tinggal sebagaimana harapan masyarakat tersebut.

Selanjutnya Program Ngabandungan, yaitu program yang bertujuan mendengarkan aspirasi dan mendiskusikan solusinya langsung bersama masyarakat. Camat dan lurah diminta oleh pemerintah untuk turun langsung mendatangi masyarakat untuk mendengarkan keluh kesah dan permasalahan yang dihadapi masyarakat. Masih kurangnya penilaian masyarakat terhadap program ngabandungan yang dilaksanakan camat menunjukkan bahwa masyarakat menilai kepedulian camat masih kurang untuk melihat kondisi dan mendengarkan aspirasi masyarakat di wilayahnya. Hal ini sangat disayangkan, karena Walikota Bandung Ridwan Kamil menghendaki Program Ngabandungan menjadi budaya kerja aparatur pemerintah termasuk camat dan lurah. Melalui program ini 
sesungguhnya camat memperoleh informasi yang membantu dalam pengambilan keputusan dan tindakan yang tepat. Namun hal ini dapat dilakukan apabila camat yang bersangkutan memiliki kepedulian dan kapasitas pengambilan keputusan berdasarkan potensi dan pemecahan masalah ada. Oleh karena itu, penilaian masyarakat ini menjadi evaluasi bagi Pemerintah Kota untuk mengetahui kendala yang dihadapi camat dalam melaksanakan Program Ngabandungan tersebut, sekaligus menilai kinerja dan kapasitas yang dimiliki Camat untuk melaksanakan program tersebut. Apabila camat dinilai tidak mampu melakukan program-program tersebut maka penilaian ini menjadi bahan pertimbangan bagi Walikota Bandung untuk lebih selektif lagi dalam penempatan pejabat pemimpin di tingkat kewilayahan yakni camat dan lurah berdasarkan penilaian kompetensi, kapasitas, dedikasi dan integritas yang sesuai dengan kebutuhan pembangunan di tingkat kewilayahan (kecamatan dan kelurahan).

Kriteria kedua penilaian warga masyarakat berkaitan dengan kinerja pelayanan meliputi kualitas layanan yang diberikan dan rata-rata waktu pelayanan. Adapun kualitas layanan yang diberikan kecamatan tersebut meliputi :

1. Surat pengantar pengurusan

KTP ke Dinas Kependudukan dan Pengambilan Foto
2. Surat pengantar pengurusan KK ke Dinas Kependudukan

3. Surat Pengantar Pengurusan surat keterangan kelahiran ke Dinas Kependudukan

4. Persetujuan surat keterangan atas tanah untuk pengurusan sertifikat tanah

5. Persetujuan ijin domisili perusahaan : persetujuan surat keterangan

6. Persetujuan surat keterangan pindah

7. Persetujuan surat keterangan tidak mampu

8. Surat keterangan pensiun

9. Persetujuan surat keteragan pengakuan anak

Layanan-layanan diatas merupakan layanan rutin dan wajib ada di setiap kecamatan yang dapat langsung dirasakan oleh seluruh lapisan kelompok masyarakat. Untuk penilaian kualitas pelayanan yang dilaksanakan kecamatan termasuk mendapat apresiasi penilaian yang baik dari masyarakat. Hal ini terlihat dari cukup banyakanya kecamatan yang memperoleh penilaian dari masyarakat dengan nilai indeks 4 dan 3. Meskipun kecamtan yang memperoleh nilai indek 2 dan 1 jumlahnya tidak sedikit, namun prestasi atas kualitas layanan yang diberikan masing-masing kecamatan cukup berimbang dan kompetitif. Hasil penilaian warga masyarakat terhadap kualitas layanan yang diberikan kecamatan dapat dilihat pada Tabel 2 di bawah ini. 
Tabel 2. Penilaian Rata-Rata Warga Kota Bandung Terhadap Kualitas Pelayanan yang Dilakukan Kecamatan

\begin{tabular}{|l|l|c|l|l|c|}
\hline No & \multicolumn{1}{|c|}{ Kecamatan } & $\begin{array}{c}\text { Indeks } \\
\text { Penilaian }\end{array}$ & No & Kecamatan & $\begin{array}{c}\text { Indeks } \\
\text { Penilaian }\end{array}$ \\
\hline 1 & Bandung Kidul & 4,24 & 16 & Lengkong & 2,50 \\
\hline 2 & Mandalajati & 4,08 & 17 & Antapani & 2,55 \\
\hline 3 & Ujung Berung & 3,90 & 18 & Batununggal & 2,52 \\
\hline 4 & Cicendo & 3,67 & 19 & Cidadap & 2,47 \\
\hline 5 & Regol & 3,53 & 20 & Kiaracondong & 2,35 \\
\hline 6 & Cibeunying Kidul & 3,53 & 21 & Bojongloa Kidul & 2,30 \\
\hline 7 & Arcamanik & 3,50 & 22 & Bojongloa Kaler & 2,24 \\
\hline 8 & Rancasari & 3,39 & 23 & Buah Batu & 2,18 \\
\hline 9 & Sukajadi & 3,18 & 24 & Babakan Ciparay & 2,17 \\
\hline 10 & Andir & 3,16 & 25 & Sumur Bandung & 2,00 \\
\hline 11 & Sukasari & 3,08 & 26 & Panyileukan & 1,88 \\
\hline 12 & Bandung Wetan & 2,95 & 27 & Cibiru & 1,88 \\
\hline 13 & Gede Bage & 2,91 & 28 & Bandung Kulon & 1,60 \\
\hline 14 & Cibeunying Kaler & 2,69 & 29 & Coblong & 1,37 \\
\hline 15 & Cinambo & 2,60 & 30 & Astana Anyar & 1,33 \\
\hline
\end{tabular}

Sumber : Bagian Pemerintahan Umum Sekretariat Daerah Kota Bandung, 2016

Berdasarkan data yang tercantum pada Tabel 2 di atas, penilaian yang diberikan masyarakat Kota Bandung terhadap kualitas layanan kecamatan, mendapatkan apresiasi yang cukup baik. Penilaian terhadap kualitas layanan yang dilaksanakan oleh kecamatan yang mencapai penilaian dengan indeks 4 (yakni kategori baik) ada di dua kecamatan yaitu Kecamatan Bandung Kidul dan Kecamatan Mandalajati. Sedangkan kualitas layanan kecamatan yang mendapat nilai indeks 3 (cukup baik) diperoleh 9 kecamatan, sebagian besar kecamatan memperoleh evaluasi tentang kualitas layanan masuk kategori penilaian kurang baik (indeks 2) dan 5 kecamatan mendapat penilaian buruk (indeks 1) dari warga masyarakat, yaitu Kecamatan Panyileukan, Cibiru, Bandung Kulon, Coblong, dan Astana Anyar. Penilaian atas kualitas layanan kecamatan ini menunjukkan kinerja kecamatan dalam melayani masyarakat menunjukkan perubahan positif, yang mana masyarakat merasa nyaman terhadap pelayanan yang diberikan, mulai dari keramahan, kejelasan intruksi pelayanan dan kenyamanan tempat pelayanan. Tentu saja bagi kecamatan yang belum memperoleh apresiasi baik dari masyarakat perlu meningkatkan kinerjanya kembali serta perlu adanya pembinaan dari pihak Pemerintah Kota (yakni tugas Bagian Pemerintahan Umum 
Sekretariat Daerah Kota Bandung) sebagai pembina kewilayahan.

Berbanding terbalik dengan kualitas pelayanan yang diberikan. Meskipun masyarakat menilai bahwa kualitas layanan cukup baik, namuan penilaian kualitas layanan tidak memperoleh angka sempurna karena rata-rata waktu pelayanan yang dapat diselesaikan oleh kecamatan sebagian besar belum memuaskan masyarakat. Rata-rata waktu pelayanan yang dapat diselesaikan oleh kecamatan masih dalam rentang diatas 1 minggu hingga hitungan bulan (sebanyak 20 kecamatan dari jumlah keseluruhan 30 kecamatan). Hanya 10 kecamatan saja yang mampu menyelesaikan waktu pelayanan ideal dengan rata-rata 5 hari kerja hingga 1 minggu. Bahkan Kecamatan Sumur Bandung mendapatkan apresiasi yang terbaik dengan rata-rata waktu pelayanan kurang dari 1 hari. Sedangkan penilaian terburuk atas rata-rata waktu pelayanan yang dapat diselesaikan adalah Kecamatan Cibiru dengan rata-rata waktu pelayanan yang dapat diselesaikan lebih dari 3 bulan (atau rata-rata 117,50 hari) . Data hasil penilaian rata-rata waktu pelayanan yang dapat diselesaikan oleh kecamatan dapat di lihat pada tabel 3 di bawah ini.

Tabel 3. Penilaian Warga Kota Bandung terhadap Rata-Rata Waktu Pelayanan Kecamatan (dalam satuan hari)

\begin{tabular}{|c|l|c|c|l|c|}
\hline No & Kecamatan & $\begin{array}{c}\text { Indeks } \\
\text { Penilaian }\end{array}$ & No & Kecamatan & $\begin{array}{c}\text { Indeks } \\
\text { Penilaian }\end{array}$ \\
\hline 1 & Sumur Bandung & 0,67 & 16 & Lengkong & 19,50 \\
\hline 2 & Cibeunying Kidul & 1,00 & 17 & Cibeunying Kaler & 20,21 \\
\hline 3 & Gede Bage & 1,13 & 18 & Rancasari & 20,50 \\
\hline 4 & Antapani & 2,56 & 19 & Cidadap & 27,00 \\
\hline 5 & Andir & 2,75 & 20 & Bojongloa Kaler & 28,50 \\
\hline 6 & Bandung Kidul & 3,33 & 21 & Babakan Ciparay & 29,29 \\
\hline 7 & Panyileukan & 4,00 & 22 & Astana Anyar & 30,00 \\
\hline 8 & Mandalajati & 4,50 & 23 & Bandung Wetan & 30,00 \\
\hline 9 & Ujung Berung & 7,18 & 24 & Buah Batu & 31,79 \\
\hline 10 & Bandung Kulon & 7,80 & 25 & Regol & 35,38 \\
\hline 11 & Cicendo & 8,83 & 26 & Bojongloa Kidul & 38,40 \\
\hline 12 & Sukajadi & 9,25 & 27 & Coblong & 45,00 \\
\hline 13 & Kiaracondong & 10,42 & 28 & Batununggal & 45,53 \\
\hline 14 & Cinambo & 12,67 & 29 & Sukasari & 54,50 \\
\hline 15 & Arcamanik & 16,70 & 30 & Cibiru & 117,50 \\
\hline
\end{tabular}

Sumber : Bagian Pemerintahan Umum Sekretariat Daerah Kota Bandung, 2016 

$\begin{array}{ll}\text { Berdasarkan } & \text { penilaian-penilaian } \\ \text { yang diberikan masyarakat diatas }\end{array}$ menjadi bahan evaluasi bagi Walikota dan Wakil Walikota Bandung dalam memantau dan menilai kinerja kecamatan. Atas partisipasi masyarakat dalam memberikan penilaian kinerja kecamatan ini ditangapi oleh salah satu camat di Kota Bandung, yang mengatakan bahwa partisipasi masyarakat Kota Bandung dalam mengevaluasi kinerja pemerintah kecamatan melalui aplikasi Sistem Informasi Penilaian (SIP) Bandung Juara tersebut masih terbilang rendah. Karena, sejak aplikasi SIP Bandung Juara ini diluncurkan pertama kali pada tahun 2014, hanya beberapa orang saja yang bersedia mengisi penilaian di SIP Bandung Juara tersebut. Menurut camat tersebut, Terdapat beberapa kendala yang dihadapi terkait mendorong partisipasi masyarakat untuk memberikan penilaian, diantaranya adalah 1) tidak semua warga masyarakat mengetahui adanya aplikasi dan manfaat dari sistem Penilaian SIP kecamatan/kelurahan, 2) tidak semua masyarakat yang memperoleh layanan mengetahui cara menggunakan perangkat komputer maupun telepon genggam untuk mengakses aplikasi tersebut. Selain itu, diharapkan melalui aplikasi SIP Bandung Juara ini juga, masyarakat dapat memberikan masukan konstruktif terkait perbaikan di bidang penyelenggaraan pemerintahan dan pelayanan umum. Namun sayangnya, dari semua penilaian masyarakat yang masuk melalui aplikasi tersebut, sangat jarang adanya komentar, masukan atau gagasan-gagasan terkaita perbaikan pelayanan yang perlu dilakukan oleh pemerintah kecamatan. Hal ini menunjukkan bahwasanya masyarakat pada dasarnya tidak peduli atau bahkan tidak mengetahui apa yang sebaiknya harus dilakukan pemerintah kecamatan. Minimnya partisipasi warga masyarakat Kota Bandung maupun masyarakat yang memperoleh layanan menunjukkan bahwa aplikasi SIP Bandung Juara belum sepenuhnya dimanfaatkan, hingga dapat dikatakan bahwa penilaian kinerja kecamatan belum menunjukkan evaluasi kinerja yang sesungguhnya.

\section{Gambar 1 Kegiatan Penilaian Masyarakat Melalui Aplikasi SIP Bandung Juara, di Kecamatan Cibiru}




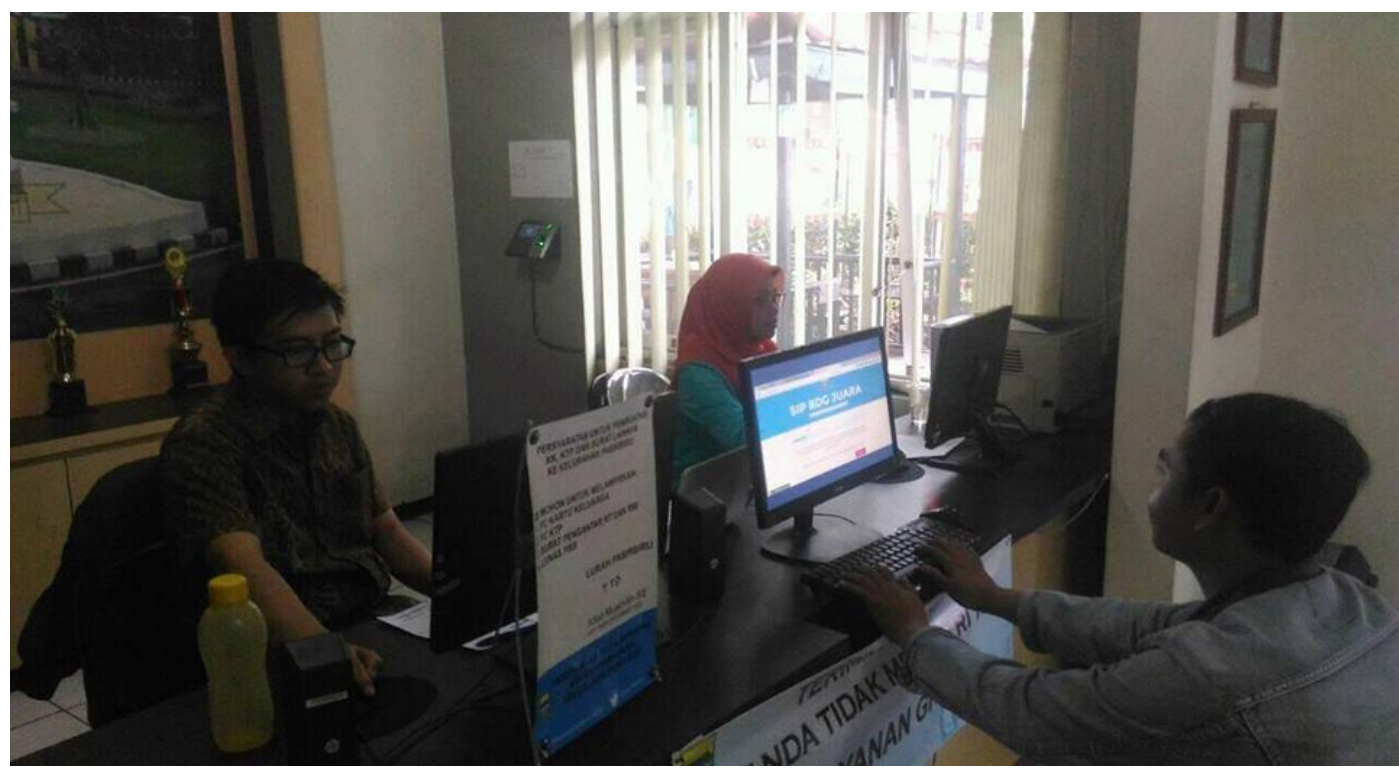

Berdasarkan pernyataan dari masyarakat memang membenarkan pernyataan camat di atas bahwa belum semua masyarakat mengetahui adanya aplikasi penilaian SIP tersebut. Namun, meskipun masyarakat dapat memberikan penilaian melalui aplikasi SIP Bandung Juara tersebut, masyarakat masih merasa pesimis atas respon pemerintah akan perbaikan kinerja berdasarkan hasil penilaian yang diberikan, bahkan masyarakat juga pesismis terhadap respon yang cepat dari pemerintah atas masukan atau kritik yang disampaikan masyarakat. Sehingga, kesadaran untuk memberikan penilaian tersebut masih sangat kurang dibandingkan jumlah keseluruhan penduduk yang ada di masing-masing wilayah kecamatan. Minimnya partisipasi masyarakat ini sangat disayangkan karena penilaian yang diberikan masyarakat tersebut dapat menjadi umpan balik bagi Pemerintah Kota Bandung khususnya menjadi bahan pertimbangan bagi Walikota Bandung untuk mengeluarkan rapor online kepada setiap camat dan lurah terkait pencapaian kontrak kinerja yang telah disepakati bersama Camat dengan Walikota.

$$
\text { Kinerja pemerintah }
$$

kecamatan memang dapat dinilai dari kualitas pelayanan umum yang sudah menjadi tugas pokok dan fungsi masing-masing pemerintah baik camat dan lurah untuk memenuhi kebutuhan masyarakat di kewilayahan. Pelaksanaan tugas pokok dan fungsi tersebut, menjadi kewajiban camat selaku pemimpin di kewilayahan sebagai Peraturan Walikota Nomor 185 Tahun 2015 tentang Pelimpahan Urusan Walikota Kepada Camat dan Lurah. Khususnya camat mempunyai peranan yang sangat strategis untuk membina, mengarahkan, dan mendorong kinerja aparatur dibawahnya dalam pelaksanaan urusan dan tugas-tugas yang telah diamantkan dalam Perwal tersebut. 
Keberhasilan pelaksanaan tugas pokok dan fungsi camat ini dapat terlaksana secara efektif, efisien dan akuntabel bilamana camat mampu menggunakan kepemimpinan dan kapasitasnya untuk mengambil tindakan dan keputusan strategis serta mengerahkan aparatur dibawahnya agar dapat meningkatkan kualitas kinerja dan memenuhi harapan masyarakat.

Berdasarkan hasil penelitian mengenai partisipasi masyarakat dalam memberikan penilaian kepada pemerintah kecamatan, menunjukkan bahwa kinerja kecamatan belum sepenuhnya maksimal dalam memberikan pelayanan kepada masyarakat. Hal ini terkait kinerja kecamatan dalam mewujudkan Kebersihan, Keindahan, Ketertiban (K3), indeks kebahagiaan, dan program ngabandungan di kewilayahan dan lingkungan tempat tinggal masyarakat. Meskipun kualitas layanan sudah mengalami peningkatan namun rata-rata waktu penyelesaian pelayanan masih belum ideal. Penilaian kinerja tersebut diatas menunjukkan kinerja kecamatan meliputi efektifitas dan efisiensi dalam pelayanan, daya tanggap dan ketepatan dalam melaksanakan tugas-tugas pemerintahan di kecamatan. Dalam hal ini, Camat sebagai pimpinan tertinggi di kewilayahan harus mampu mengemban tugas yang dilimpahkan kepadanya karena camat memegang peranan penting dan strategis, sekaligus penanggung jawab pelaksanaan tugas-tugas pemerintahan dan pembangunan.

Kehendak Walikota agar kinerja kecamatan menjadi obyek pengawasan dari masyarakat merupakan langkah maju dalam proses penyelenggaraan pemerintahan termasuk tercapainya tujuan politik dari desentralisasi, yakni penyelenggaraan urusan pemerintahan di daerah harus sepenuhnya didukung oleh keterlibatan masyarakat, baik ditingkat perencanaan, pelaksanaan, maupun pengawasan. Hal ini dilakukan semata-mata agar terwujud pemerintahan yang berorientasi pada melayani, mengayomi, dan melindungi masyarakat terhadap pemenuhan kebutuhan dalam seluruh aspek kehidupannya. Terkait masih minimnya partisipasi masyarakat dalam melakukan pengawasan kinerja kecamatan, perlu adanya upaya yang dapat menggerakan inisiatif dan kepedulian masyarakat untuk secara sadar turut serta mendukung pelaksanaan program dan mengawasi penyelenggaraan pemerintahan di tingkat kewilayahan agar tujuan dan cita-cita penyelenggaraan pemerintahan yang baik dan melayani dapat diwujudkan bersama-sama. Upaya mendorong kepedulian dan kesadaran masyarakat untuk mengawasi kinerja pemerintahan menjadi tantangan tersendiri. Terlebih lagi di Kota Bandung, yang mana nilai-nilai sosial masyarakat yang sudah bergeser kepada nilai layaknya masyarakat kota besar yang bersifat 
individualis, pragmatis dan materialistis. Masyarakat pada kotakota besar umumnya disibukkan pada pemenuhan urusannya sendiri, sedangkan urusan-urusan yang sifatnya harmonisasi kehidupan sosial, pelayanan publik, kebersihan dan keindahan kota lebih diserahkan tanggung jawabnya kepada pemerintah. Masyarakat merasa sudah menjadi kewajiaban pemerintah untuk memenuhi kebutuhan masyarakat disamping mereka juga merasa sudah membayar pajak. Oleh karena itu, sudah sepantasnya pemerintah bekerja dengan lebih baik untuk memenuhi kebutuhan-kebutuhan sosial tersebut, tidak peduli akan hambatanhambatan yang dihadapi. Masyarakat merasa pemerintah tidak perlu mereka awasi karena sudah ada mekanisme hukum yang seharusnya menegakan keadilan dan menindak setiap penyimpangan-penyimpangan yang dilakukan pemerintah dalam melaksanakan tugas pokok dan fungsinya. Disisi lain, masyarakat juga merasa bahwa keterlibatan mereka tidak memiliki kontribusi banyak bagi perubahan keadaan daripada kinerja pemerintah, sikap apatis ini menimbulkan ketidakpedulian meskipun masyarakat merasa tidak puas, namun masyarakat merasa tidak dapat berbuat banyak untuk menghasilkan sebuah perubahan. Oleh karena itu perubahan dan peningkatan kinerja sepatutnya berasal dari diri aparatur dan pemimpin pemerintah sendiri untuk lebih memperhatikan masyarakat di wilayahnya.

Keterlibatan masyarakat dalam pengawasan, memang tidak menimbulkan konsekuensi pada pemberian sanksi kepada pemerintah, namun setidaknya pengawasan tersebut sebagai perwujudan dari akuntabilitas kinerja pemerintah kepada publik. Disamping itu pula, pengawasan masyarakat sebagai sarana komunikasi serta membangun kebersamaan antara pemerintah (kecamatan) dengan masyarakat di wilayahnya untuk bekerja sama membangunan kehidupan bernegara yang lebih baik. Melalui pengawasan masyarakat ini, diharapkan dapat menjadi refleksi bagi pemerintah khususnya di kecamatan yang banyak berhubungan langsung dengan masyarakat, untuk memberikan pelayanan publik sebaik-baiknya, sebagai pelayan masyarakat bukan minta dilayani. Pemerintah kecamatan juga perlu berinovasi untuk memangkas beberapa prosedur birokrasi yang terkesan berbelit-belit, serta memberikan informasi dan sosialisasi mengenai standar operasional prosedur setiap pelayanan yang diberikan sehingga masyarakat menjadi paham, tidak harus bolak-balik memakan waktu dan tenaga hanya untuk menyelesaikan sebuah urusan administrasi pemerintahan. Termasuk menghapus kebiasaankebiasaan dalam pelayanan yang melanggar norma-norma hukum seperti pungutan liar yang membuat 
masyarakat merasa tidak nyaman dan tidak puas akan pelayanan yang diberikan dalam penilaiannya. Disamping, belum optimalnya pelayanan publik di kecamatan dengan segala aspeknya disebabkan oleh berbagai faktor antara lain keterbatasan sumber daya manusia baik kuantitas maupun kualitas, sarana dan prasarana pelayanan yang belum memadai, keterbatasan dukungan anggaran dan ketidakjelasan pembagian kewenangan.

Bagaimanapun kinerja pemerintah daerah dan kecamatan semakin banyak mendapat sorotan tajam baik dari pemerintah pusat, lembaga sosial maupun individuindividu dalam pemenuhan tuntutan akan hak-hak yang harus diterima oleh masyarakat. Hal ini merupakan konsekuensi dari pemerintah kecamatan, karena bagaimanapun kecamatan sebagai unit-unit pelaksana tugas pemerintahan di kewilayahan yang berhubungan langsung dengan masyarakat. Kegiatan apapun yang terjadi di kewilayahan dipandang masyarakat sebagai tanggung jawab pemerintah kecamatan dan kelurahan. Pemerintah kecamatan dalam mencapai kinerja yang berkualitas harus mampu merespon kebutuhankebutuhan masyarakat di wilayahnya secara optimal. Kompetensi, kapasitas dan sumber daya bagi perangkat pemerintah kecamatan perlu mendapat perhatian ekstra dan menjadi bahan pertimbangan dari para pembuat kebijakan dan pemimpin tertinggi Pemerintah Kota Bandung yakni Walikota dan Wakil Walikota, terutama dalam hal penempatan pejabat dan aparatur pendukung serta ketersediaan sumber daya (anggaran maupun sarana dan prasarannya), sehingga apa yang selama ini menjadi tuntutan dan harapan masyarakat dapat terwujud. Ketidaksiapan dan juga kemampuan perangkat kecamatan (termasuk di kelurahan) belum memiliki kapasitas secara obyektif memadai. Disamping, masalah etos kerja dan kedisiplinan aparatur kecamatan dalam menjalankan tugasnya yang membuat rata-rata waktu pelayanan menjadi lama. Kepemimpinan camat dalam mengawasi atau mengontrol pelaksanaan tugas yang dikerjakan oleh aparatur pegawainya juga dinilai masih lemah yang membuat kinerja kecamatan harus senantiasa ditingkatkan.

Upaya ini tentu saja perlu mendapat perhatian dari masyarakat, artinya masyarakat juga perlu mendesak Pemerintah Kota Bandung menyiapkan segala sumber daya, keberpihakan mendukung terwujudnya tata kelola pemerintahan yang baik di kecamatan, termasuk memberlakukan serta sanksi yang tegas bagi pejabat dan aparatur kecamatan yang memiliki kinerja yang tidak sesuai. Partisipasi masyarakat dalam pengawasan kinerja pemerintah (kecamatan) sangat diperlukan agar terus terciptanya evaluasi secara simultan dalam setiap penyelenggaraan 
pemerintah yang langsung berhubungan dengan pelayanan publik di segala tingkatan (mulai dari pelayanan pemerintahan di tingkat Kota maupun kewilayahan). Partisipasi masyarakat dalam melakukan pengawasan terhadap kinerja pemerintah (kecamatan) merupakan esensi dari demokrasi yang meletakkan kedaulatan di tangan rakyat. Masyarakat yang membentuk pemerintahan (melalui seleksi politik pemilihan kepala daerah pada pemilukada), maka masyarakat pula yang mengawasi kinerja kepala daerah termasuk kepemimpinan dan manajemen pemerintahan yang dibangunnya hingga ke unit-unit pemerintah daerah yang berada dalam lingkup kewilayahannya, yakni perangkat pemerintah di wilayah kecamatan.

$$
\text { Partisipasi masyarakat }
$$

merupakan unsur penting dalam menunjang keberhasilan pelaksanaan suatu program pemerintah. Melalui pemberlakuan aplikasi SIP Bandung Juara menyediakan wadah bagi masyarakat untuk mengevaluasi kinerja kecamatan sebagai bentuk penyelenggaraan pemerintah yang berorientasi pada kebutuhan masyarakat, dan juga untuk memenuhi unsur keadilan dan pemberdayaan masyarakat agar peduli terhadap penyelenggaraan pemerintahan dan peningkatan kualitas pelayanan publik di kecamatan. Partisipasi masyarakat bisa menjadi bagian yang mendukung keberhasilan pemerintah kecamatan dalam melaksanakan pelayanan publik dan mewujudkan lingkungan tempat tinggal yang baik dan layak bagi masyarakat. Partisipasi masyarakat dalam pengawasan melalui aplikasi SIP Bandung Juara perlu terus ditumbuhkan dalam rangka keberlanjutan upaya peningkatan kinerja pemerintah kecamatan dan keberhasilan program pembangunan di kewilayahan.

\section{KESIMPULAN}

Website SIP Bandung Juara merupakan wadah aspirasi bagi warga masyarakat untuk memberikan penilaian terhadap kinerja kecamatan. Selain memberikan penilaian, masyarakat juga dapat memberikan kritik, saran, masukan berupa ide dan gagasan mengenai apa yang sebaiknya perlu dilakukan pemerintah kecamatan dalam penyelenggaraan tugas-tugas pemerintahan dan pelaksanaan pelayanan publik yang lebih baik. Berdasarkan hasil penilaian masyarakat, kinerja kecamatan dalam mewujudkan kebersihan, ketertiban dan keindahan (K3), indeks kebahagian, dan program ngabandungan belum begitu optimal dan memuaskan. Sedangkan kinerja kualitas pelayanan mendapat penilaian cukup baik, dan perlu perbaikan dalam hal rata-rata waktu pelayanan yang belum ideal. Penilaian masyarakat melalui aplikasi SIP Bandung Juara menjadi indikator penilaian dan bahan pertimbangan bagi walikota untuk senantiasa meningkatkan kualitas 
kinerja dan pelayanan unit-unit kerja perangkat daerah khususnya di kewilayahan (kecamatan dan kelurahan). Dalam meningkatkan kinerja kecamatan, diperlukan keberpihakan dan komitmen pemimpin dan para pembuat kebijakan mengenai penempatan pejabat dan aparatur kecamatan berdasarkan kompetensi dan kapasitasnya, legalitas atau payung hukum mengenai kewenangan setiap pelaksanaan program, penyediaan sarana prasarana dan sumber daya yang dibutuhkan.

Partisipasi masyarakat Kota Bandung dalam memberikan penilaian terhadap kinerja kecamatan di wilayah tempat tinggalnya terbilang masih minim dibandingkan jumlah keseluruhan penduduk di masing-masing wilayah kecamatan. Hal ini menunjukkan bahwa masyarakat belum memanfaatkan aplikasi SIP Bandung Juara sepenuhnya dalam memberikan kritik dan masukan. Partisipasi masyarakat dalam memberikan penilaian menjadi kunci keberhasilan penyelenggaraan pemerintahan dan pelaksanaan pembangunan di daerah. Oleh karena itu, Pemerintah Kota Bandung khususnya pada bagian Pemerintahan Umum perlu melakukan upaya sosialisasi yang lebih intensif kepada masyarakat mengenai Sistem Informasi Penilaian (SIP) Bandung Juara agar masyarakat semakin peduli dan sadar akan pentingnya keterlibatan mereka dalam memantau dan mengevaluasi (participation in evaluation) kinerja pemerintah kecamatan dalam rangka perbaikan dan peningkatan di masa depan.

\section{DAFTAR PUSTAKA}

Arend, N, D. Corry, W.Hatter, J. Le Grand, and A.Lent. 2004. Choice: What Role Can It Play in Helping Local Public Services Evolve, London: New Local Government Network

Atmosudirdjo, Pradjudi. 1997. "Membangun Visi dan Orientasi Kinerja Aparatur Daerah: Menjawab Tantangan Masyarakat Indonesia Baru" Manajemen Pembangunan, Nomor 19 Tahun V April 1997, 11- 19

Beck, D. and C. Cowan. 1995. Spiral Dynamics: Mastering Values, Leadership and Change, Oxford: Blackwell Publishing Cohen and Uphoff. $1977 . \quad$ Rural Development Participation, Cornel University. New. York

Conyers, Diana. 1994. Perencanaan Sosial di Dunia Ketiga: Suatu Pengantar,Yogyakarta:

Gadjah Mada University Press

Keban, Yeremias. T. 2004. Enam Dimensi Strategis

Administrasi Publik,

Yogyakarta : Gava Media

Moleong, Lexy.J. 2011, Metode Penelitian Kualitatif, Bandung : PT. Remaja Rosda Karya. 
Rathnakar, G. 2012. “A Study Of

Workers Participation In

Management Decision

Making At Bhel, Hyderabad".

International Journal of

Marketing, Financial

Services \& Management

Research. Vol.1 Issue 9,

September 2012, 135-141

Scolve, R. 1995. Democracy and

Technology, New York:

Guilford Press

Sendjaja, Denny Wahyu, Gregorius

Yorrie Rismanto, dan Nico

Andrianto, 2015. Analisis

Kebijakan Publik dalam

Pemeriksaan Kinerja, dalam

Jurnal Tata Kelola dan

Akuntabilitas Keuangan

Negara, Volume 1, Nomor 1,

Juli 2015, hal. 67-81

Siagian, Sondang P.

1994.Administrasi

Pembangunan, Jakarta: PT.

Gunung Agung.

Skinner, S. 1997, Building

Community Strengths: A

Resource Book on Capacity

Building. London:

Community Development

Foundation.

Peraturan Walikota Bandung Nomor

185 Tahun 2015 Tentang

Pelimpahan Sebagian Urusan

Walikota Kepada Camat dan

Lurah

Undang-Undang Nomor 23 Tahun

2014 Tentang Pemerintah

Daerah 